ELORE (ISSN 1456-3010), vol. 17 - 1/2010.

Julkaisija: Suomen Kansantietouden Tutkijain Seura ry.

[http://www.elore.fi/arkisto/1_10/ajankoht_pitkasalo_1_10.pdf]

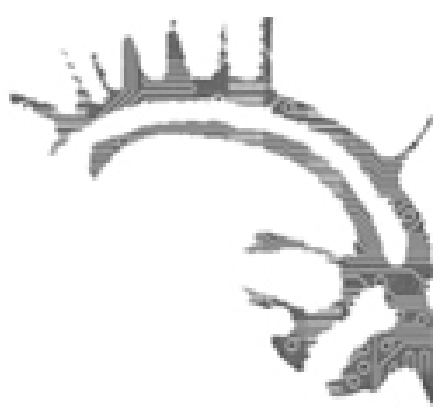

\title{
KALEVALAISIA SANKAREITA JA INTERTEKSTUAALISIA SIIRTyMiä Johanna Sinisalon ROMAanissa SANKaRIT
}

\author{
Lectio praecursoria Jyväskylän yliopistossa 7.11.2009
}

\section{$\underline{\text { Eliisa Pitkäsalo }}$}

Taiteen pitkän historian varrelta löytyy hyvin erilaisia kokeiluja mytologian henkilöhahmojen ja muun myyttisen aineksen siirtämisestä uuteen kontekstiin. Eri taidelajeja edustavien teosten motiiveina on usein käytetty - ja käytetään edelleen - vanhoja myyttejä. Jumalia, puolijumalia ja heeroksia on lainattu erilaisten tekstien rakennusaineiksi jo kauan ennen postmodernistista, jopa modernistista aikaa. Niinpä ei olekaan mitenkään uutta ja odottamatonta, että myös nykykirjallisuudessa käytetään erilaisiin narratiivisiin tehtäviin myyttisiä aineksia.

Suomalaisessa kulttuurikontekstissa myyttisten ainesten päälähde on luonnollisesti kansalliseepos Kalevala (Vanba Kalevala ilmestyi vuonna 1835, Uusi Kalevala vuonna 1849), jolla on erityinen merkitys suomalaisen taiteen muovautumisessa sellaiseksi kuin se nykypäivänä on. Kuvataiteilijat, säveltäjät, muotoilijat, eri lajien sanataiturit ja monien muiden taidemuotojen edustajat ovat käyttäneet teemoja ja motiiveja, joita tästä Elias Lönnrotin luomasta runoelmasta löytyy runsain mitoin. Kalevalaisten aiheiden käyttö inspiraation lähteenä oli erityisen laajaa karelianismin aikana 1800-1900-luvun vaihteessa, jolloin useat suomalaisen kulttuurin edustajat pyrkivät rakentamaan suomalais-kansallista identiteettiä vahvistamalla Kalevalan välittämää kuvaa suomalaisten myyttisestä menneisyydestä. Esimerkkeinä voidaan mainita Eino Leinon myyttisten ainesten uudelleenkäyttö lyriikassa (esimerkiksi Helkavirret 1903, 1916, Väinämöisen kosinta 1905), Akseli Gallen-Kallelan Kalevala-kuvitukset ja Jean Sibeliuksen Kalevalaaiheinen musiikki (Kullervo-sinfonia 1892 ja Lemminkäinen-sarja 1897).

Kansallinen aarteemme Kalevala on ollut useaan kertaan menettämässä arvoaan, mutta aina on tullut uusia taiteellisten kokeilujen aaltoja, jotka ovat nostaneet eepoksen jälleen alkuperäiseen arvoonsa merkitykselliseksi suomalaisen kulttuurin perustaksi. Kalevala-kultti on ajoittain syttynyt ja sytyttänyt taiteilijoita luomaan uusia tulkintoja. Kalevalaa on käytetty kirjallisten ja visuaalisten teosten pohjana (romaanit, runoelmat, 
Eliisa Pitkäsalo: Kalevalaisia sankareita ja intertekstuaalisia siirtymiä

draamat, elokuvat, rock-teokset, roolipelit, kuvakirjat ja sarjakuvat vain muutamia mainitakseni). Nämä kokeilut ovat tuoneet Kalevalan mytologisen maailman nykylukijan ulottuville. Esimerkiksi Mauri Kunnaksen Koirien Kalevalaa lukemalla lapset pääsevät helpommin perille Kalevalan kuvaamista tapahtumista.

\section{JohanNa Sinisalon $S_{A N K A R I T}$}

Kalevalasta ammentavien joukkoon liittyi myös aiemmin scifi-novellistina ja draamakirjailijana tunnettu Johanna Sinisalo romaanillaan Sankarit (2003). Hän oli kolme vuotta aiemmin, vuonna 2000, voittanut Finlandia-palkinnon fantasia-sävytteisellä realistisen romaanin rakennetta rikkovalla esikoisromaanillaan Ennen päivänlaskua ei voi, jossa ihmishenkilöhahmojen joukkoon liittyy peikkonuorukainen. Toisessa romaanissaan Sinisalo jatkaa myyttien uudelleenkerrontaa: hän sijoittaa kalevalaiset mytologiset hahmot nykymaailmaa kuvaavaan ympäristöön. Näin Kalevalan miespuoliset heerokset saavat uudet roolit rocklaulajana, iskelmätähtenä, huippu-urheilijana, jääkiekkovalmentajana ja yhdistettynä it-alan asiantuntijana ja muusikkona, kun taas naispuoliset hahmot siirtyvät uuteen ympäristöönsä tutkimuskeskuksen johtajana, korkeasti koulutettuna entisenä kauneuskuningattarena, valokuvamallina, poikansa managerina, performaatiotaiteilijana ja sankariäitinä.

Rakenteeltaan Sankarit seuraa melko uskollisesti Kalevalan eepoksille tyypillistä katkonaista rakennetta. Tästä syystä romaanin rikkonaisuuden vaikutelma korostuu ja tuntuu ajoittain jopa häiritsevältä. Sinisalo tavallaan palauttaa ajatuksen Kalevalasta siihen suunnitelmaan, joka Lönnrotilla kansanrunoja kerätessään alun perin oli, kun hän kirjasi materiaalia pienoisrunoelmia varten. Tosin Sankareiden henkilöhahmot eivät yleensä peilaa kansanrunouden hahmoja vaan jo kalevalaisia, Lönnrotin muokkaamia. Lönnrot loi henkilöhahmoja ja tarinoita liittämällä yhteen eri runoista aihelmia ja jopa paikkaili tarinoihin jääviä aukkokohtia. Nämä Lönnrotin vaivoin rakentamat hahmot joutuvat kovaan käsittelyyn Sinisalon teoksessa, kun ne nimenannon ja kollaasimaisesti liitettyjen tekstikatkelmien kautta hajotetaan jälleen osiin.

Sankarit rikkoo realistiselle kirjallisuudelle tyypillisen kahtiajakautuneisuuden rajan esimerkiksi sekoittamalla niin kutsutusti korkeaan ja matalaan kuuluvia lajeja: eeposta, tragediaa, satua, scifiä, romanssia ja jännitysromaania. Lisäksi muun kerronnan lomaan on liitetty uutisia, kolumni, pakina, haastatteluja, lehtiartikkeleita, poliisin etsintäkuulustelupöytäkirja, mielipidekirjoitus, graffiti ja kirje. Sinisalo käyttää eri lajeihin kuuluvia tekstikatkelmia eri tehtäviin. Toisaalta ne vievät kertomusta eteenpäin, toisaalta ne kuvaavat eri henkilöhahmojen luonnetta.

Jo Kalevalasta voidaan löytää eri lajeihin viittaavia rakenteita ja sisällöllistä tematiikkaa, joita paisuttamalla Sinisalo on rakentanut oman lajihybridinsä. Nykypäivän saippuaoopperasarjoista ja rakkausromaaneista tuttuja asetelmia löytyy jo Kalevalasta, kun vanha Väinämöinen vokottelee nuorta Ainoa, Joukahainen ampuu Väinämöistä kostoksi sisarensa kuolemantuottamuksesta, Kullervo makaa sisarensa ja ystävykset Väinämöinen ja Ilmarinen kosiskelevat samaa naista, Pohjolan neitoa. Kalevalan keskeinen tapahtuma, Sammon ympärille nivoutuva seikkailu, on toisaalta jännityskirjallisuuden ja -elokuvan perusaineistoa, toisaalta questinä myös sadun, fantasian ja etsin- 
Eliisa Pitkäsalo: Kalevalaisia sankareita ja intertekstuaalisia siirtymiä

täromanssin keskeinen osa. Itse Sampo aikansa teknologisen kehityksen korkeimpana saavutuksena sopii scifin materiaaliksi, samoin kuin pimeä Pohjola scifi-kertomuksen tapahtumapaikaksi. Näitä aineksia yhdistelemällä on syntynyt romaani, joka kertoo Kalevalan"julkkisten" sijaan median armoilla olevista nykypäivän sankareista.

Sankarit osallistuu yleiseen keskusteluun ajankohtaisista aiheista ja on hyvin kriittinen kommentoidessaan nykymaailman tilaa. Kritiikki Sankareissa kohdistuu moneen suuntaan, yhtenä keskeisenä kommentoinnin kohteena on teknologian nopea kehitys ja median merkitys sankaruuden rakentajana ja purkajana. Sinisalo osoittaa kärkevästi, miten julkkisten ylä- ja alamäillä mässäily mediassa vaikuttaa elämänkohtaloihin.

\section{KULTTUURISET MUUTOKSET JA EETTISYYS}

Romaanin teemat liittyvät yleisempiin kulttuurisiin diskursseihin. Henkilöhahmojen tarinoiden välityksellä esiin nousee vakavia eettistä keskustelua herättäviä aiheita, joiden kautta esille tulevat myös muutokset kulttuuri- ja poliittisessa ilmapiirissä, joka ympäröi modernia, länsimaista maailmaa. Kalevalasta siirrettyjä motiiveja on yhdistetty uusiin motiiveihin (Sampo/Zombie, Kullervon/Karelin hahmo ja Frankenstein-motiivi), ja niiden kautta romaanin yhdeksi keskeiseksi teemaksi nousee kysymys eettisyydestä. Esimerkiksi Karelin tarinaan siirtyvät Kalevalasta Kullervoon liittyvät teemat (sisaren turmelu, kosto ja itsemurha), mutta Sinisalon luennassa Karelin tarina linkittyy vuosituhannen vaihteessa eettistä keskustelua herättäneisiin ongelmakohtiin: kysymykseen lähisukulaisten seksuaalisesta kanssakäymisestä ja keskusteluun seksuaalisesta väkivallasta (erityisesti sotien joukkoraiskauksista) sekä terroriteoista ja itsemurhaiskuista. Näiden lisäksi Sinisalo laajentaa Karelin tarinasta luettavaa tematiikkaa myös uusiin suuntiin. Siitä voi lukea kommentin luonnonmaiseman turmelemiseen turismin ehdoilla, keskusteluun hevimusiikin satanismisyytöksistä ja kysymykseen muukalaisuudesta ja monikulttuurisuudesta.

Sankareissa toistuu uudistuneessa muodossa myös Kalevalan Sampo-motiivi: Sankareiden Zombie ${ }^{\mathrm{TM}}: \mathrm{n}$ ympärille kutoutuu yhtenä teemana kysymys eettisyydestä. Ihmemylly jauhaa rikkautta ja kuuluisuutta koehenkilöiden hyvinvoinnista piittaamattomalle omistajalleen rouva Alakorkeelle. Vuosituhannen vaihteessa ja vielä aivan viime aikoina kiivasta keskustelua on herättänyt kännyköiden ja muiden sähköisten laitteiden säteilyn vaikutus elimistöön. Sankareissa tämä kärjistyy kuvaan sähköaalloin tainnutetusta väkijoukosta. Vuosituhannen vaihteessa teknologian kehityksen kiihtyminen näkyy erityisen selkeästi länsimaissa, mutta vähitellen teknologia levittäytyy myös vielä suhteellisesti kehittymättömille alueille. Kehitys taas on tuonut tullessaan sekä positiivisia että negatiivisia vaikutuksia: urbanisoituminen, teollistuminen ja teknologian käyttöönotto kaikilla elämän alueilla ovat toisaalta helpottaneet länsimaisten ihmisten elämää, mutta niiden haittavaikutukset ovat pelottavia sekä yksilötasolla että maailmanlaajuisesti nähtynä. Ilmastonmuutoksesta johtuvat luonnonkatastrofit, koko maailman väestöä uhkaavat pandemiat ja poliittisista syistä ja uskonnon varjolla tehdyt terrori-iskut ovat lisääntyneet kiihtyvällä vauhdilla viime vuosikymmeninä.

Erityisen painon eettisyyskysymys saa, kun tarkastellaan Sankareiden yhteyttä keskusteluun, joka kommentoi teknistymistä, medioitumista ja median kasvavaa merkitystä 
Eliisa Pitkäsalo: Kalevalaisia sankareita ja intertekstuaalisia siirtymiä

tiedon nopean siirtymisen välineenä, mutta teknologian kehitykseen ja medioitumiseen ei suhtauduta yksinomaan negatiivisesti. Jo tekstikatkelmien käyttö korostaa median merkitystä prosessissa, jossa nyky-yhteiskunnassa elävä ihminen hankkii ja saa tietoa (tiedon pirstaleisuus: uutiset, internet ja niin edelleen). Vaikka Rex menettää asemansa Karelin terrori-iskun jälkeen laulujensa sanoituksiin liittyvien satanismisyytösten takia, rouva Alakorkee joutuu lähtemään maasta terveydelle haitallisten teknologisten kokeilujensa tultua ilmi, Mahti menettää mahdollisuutensa urheilijana doping-käryn vuoksi ja Oona menee veteen nähtyään Rexin kuvan lehdessä, Sankareissa osoitetaan myös, miten teknistyminen yleensä tuo mukanaan myös positiivisia seurauksia. Esimerkiksi Toinilla ei olisi mitään mahdollisuuksia löytää poikaansa maanalaisen elinpankin hyllyiltä ilman internetin apua eikä Mahti heräisi eloon ilman Toinin häneen pumppaamaa dopingainetta, joutsenlaulua, ja muuta teknistä välineistöä.

\section{SUKUPUOLI JA IDENTITEETTI}

Toiseksi keskeiseksi teemaksi nousevat feministiseen ja sukupuolen tutkimukseen liittyvät diskurssit. Henkilöhahmojen välityksellä romaani linkittyy keskusteluun (seksuaalisen) identiteetin muodostumisesta ja muodostamisesta, sukupuolten muuttuvista rooleista, oman ruumiin hallinnasta ja vallasta. Kysymys vallasta ja vallankäytöstä antavat henkilöhahmojen suhdeverkoston ja hahmojen sukupuoliroolien analysointiin merkittävän lisän. Tytti Pohjolan, entisen kauneuskuningattaren tarina välittää feministisiä merkityksiä ruumiin käytöstä vallan välineenä. Valtaan liittyvä analyysi värittää koko Tytin tarinan kärjistyen Tytin karmeassa kuolemassa, kun Karel ottaa vallan käsiinsä. Ruumiillisuuteen ja valtaan liittyvä analysointi jatkuu Tytin tarinan suhteen vielä hänen kuolemansa jälkeenkin, tosin muuttuneena ja kyberneettisesti sävyttyneenä, kun Ile rakentaa virtuaalisen naisen yrittäen siten synnyttää itselleen vaimon tai herättää Tytin henkiin.

Väinämöisen ja Ainon myyttinen tarina vanhasta shamaanista ja nuoresta neidosta saa Sinisalon kerronnassa uusia, arkipäiväämme linkittyviä sukupuoliroolien muutoksesta johtuvia poliittisia merkityksiä ja myös eettisiä sävyjä, kun Oona esitetään omasta ruumiillisuudestaan epävarmaksi nuoreksi tytöksi, jonka vanha, seksuaalisesti kokenut rock-laulaja viettelee. Oonan henkilökuva täydentyy Ainon hahmon kuvauksessakin käytetyin myyttisin veteen liittyvin symbolein ja tarjoaa uudessa kulttuurikontekstissaan luentaan feministisen näkökulman. Sekä Väinämöinen että Rex esitetään nuoruutta havittelevana vanhempana miehenä, joka myöhemmin tyytyy osaansa yksinäisenä, naisettomana miehenä. Rexin henkilökuvassa tapahtuu kuitenkin erityinen muutos, kun hän kasvaa isyyteen.

Huolimatta romaanissa käsitellyistä vakavista aiheista romaanin yleissävy ei kuitenkaan ole vakava vaan asioita tarkastellaan pilke silmäkulmassa. Esimerkiksi eepoksesta tuttuja yliluonnollisia, myyttisiä siirtymiä tuonelaan, saareen ja Sariolaan kuvataan tavalla, joka etäännyttää romaanissa kuvattujen hahmojen matkat alkuperäisestä myyttisyydestään. Sankareissa kuvatut matkat ovat osin verrattavissa Kalevalassa kuvattuihin yliluonnollisiin siirtymiin, mutta niihin on lisätty tyylillisiä kärjistyksiä: Rex hakee sanoja kärpässienen (soman) aiheuttamasta hallusinaatiotilasta, Seppo Ile Ilmarinen matkaa Sariolaan Rexin vaivihkaa antaman huumaavan lääkkeen (kukkalatva) tainnuttamana ja 
Eliisa Pitkäsalo: Kalevalaisia sankareita ja intertekstuaalisia siirtymiä

Mahti Saarelainen lentää Sariolan miesten kostoa pakoon Santorinin Caldera-saareen yksityisjetillä. Rouva Alakorkeen Zombien ${ }^{\mathrm{TM}}$ takaisinryöstömatka taas on scifin keinoin esitetty sotaretki ultrakevyine lentolaitteineen.

\section{MODERNIN JA POSTMODERNIN VÄLITILASSA}

Sankarit asettuu yhteiskuntakriittisyydessään ja ambivalenttiudessaan kiinnostavaan välitilaan keskustelussa romaanin modernistisuudesta ja postmodernistisuudesta. Parodian keinoja käyttävässä romaanissa käsitellään vakavia aiheita, jotka eivät vaikuta sopivan postmodernin ideologiaan, joka korostaa pinnassa tapahtuvaa liikettä kätkettyjen ja vasta tulkinnassa avautuvien merkitysten sijasta. Kehyksen näille aiheille antavat eri lajit, niistä yhtenä science fiction, joka asettuu tiloja purkavana ja uusia rakentavana postmodernistisen kirjallisuuden sisarlajiksi. Sankareita voidaan lukea toisaalta kriittisenä kannanottona nykyiseen maailmanmenoon, toisaalta myös mahdollisuutena vaikuttaa tapahtumien vääjäämättömältä näyttävään kulkuun. Vaikka myös Sankareissa - samoin kuin Kalevalassa - toiminnan kuvauksen keskiöön nousee taistelu rikkautta jauhavasta ihmemyllystä, joka hyvän sijaan aiheuttaa sairauksia ja osoittautuu muutenkin ongelmalliseksi, Sinisalo ei kuitenkaan lopulta maalaa eteemme apokalyptistä kauhukuvaa maailmastamme ja tulevaisuudesta. Sankarit on kertomus nyky-yhteiskunnasta ja sen raadollisuudesta, mutta kaaosmaista nyky-yhteiskuntaa esittävä dystooppista tulevaisuudenkuvaa luova pessimistinen kertomus muuttuu myyttissävytteisessä luennassa toivorikkaaksi kuvaukseksi uuden ajan alusta.

Aihepiiriltään suomalaiskansallisena Sankarit osallistuu epäsuorasti keskusteluun kansallisvaltioiden omintakeisuudesta, mutta toisaalta yhtenäistä kansallista identiteettiä ei enää luoda samalla tavoin kuin 1800-luvulla. Euroopan Unionin myötä kansojen yhdistyessä saman lipun alle monilta tahoilta on kuulunut epäilyksiä kansallisten kulttuurien säilymisen mahdollisuudesta. Sankarit liittyy tähän keskusteluun toisaalta kansallisten vahvuuksien esittäjänä ja säilyttäjänä, toisaalta kansallisten myyttien ja stereotypioiden purkajana. Suomalaisuus asettuu Sankareissa osaksi eurooppalaista tiede- ja kulttuurikehystä teknologian kehityksen kuvauksen ja kulttuuristen ikonien - muusikoiden ja urheilijoiden - menestyksekkään edustuksen ansiosta. Sankarit samanaikaisesti sekä korostaa että kritikoi tätä ilmiötä ja osoittaa syvälle luotaavan yhteyden mytologisten hahmojen ja nykypäivän kulttuuri-ikonien välillä.

Sankareiden erityisyys ei siis piile ainoastaan siinä, miten se opastaa nykylukijan selailemaan Kalevalaa tarkastaakseen romaanissa esitettyjen tapahtumien "autenttisuuden" vaan lisäksi ensinnäkin siinä, että Sinisalo kirjoittaa Kalevalaa uudelleen tavalla, joka osoittaa nykysankareiden taustalla olevat syvälle ulottuvat mytologiaan viittaavat juuret. Toiseksi romaanissa tulee esiin ikiaikaisiksi osoittautuvia ongelmia, jotka vain muuttavat muotoaan uudessa ympäristössään, esimerkiksi väkivaltaan ja vallan käyttöön liittyvä ongelmallisuus, mutta myös Sankareista allegorisessa luennassa paljastuva ikuinen hyvän ja pahan välinen taistelu ja uuden, paremman valtakunnan odotus.

Filosofian tohtori Eliisa Pitkäsalo toimii suomen kielen lehtorina LänsiUnkarin yliopistossa.

Elore $1 / 2010$ 